This is the final peer-reviewed accepted manuscript of:

Lanci A, Castagnetti C, Ranciati S, Sergio C, Mariella J. A regression model including fetal orbit measurements to predict parturition in Standardbred mares with normal pregnancy. Theriogenology. 2019 Mar 1;126:153-158.

The final published version is available online at: 10.1016/j.theriogenology.2018.12.020

(C) [2019]. This manuscript version is made available under the Creative Commons AttributionNonCommercial-NoDerivs (CC BY-NC-ND) 4.0 International License

(http://creativecommons.org/licenses/by-nc-nd/4.0/) 


\section{A REGRESSION MODEL INCLUDING FETAL ORBIT MEASUREMENTS TO PREDICT PARTURITION IN STANDARDBRED MARES WITH NORMAL PREGNANCY}

Aliai Lanci a*, aliai.lanci2@unibo.it

Carolina Castagnetti a, carolina.castagnetti@unibo.it

Saverio Ranciati b, saverio.ranciati2@unibo.it

Chiara Sergio c, chiara.sergio@studio.unibo.it

Jole Mariella a, jole.mariella2@unibo.it

a Department of Veterinary Medical Sciences, University of Bologna, Via Tolara di Sopra 50, 40064, Ozzano Emilia, Bologna, Italy.

b Department of Statistical Sciences, University of Bologna, Viale Quirico Filopanti 5, 40127 Bologna, Italy.

c Private practitioner, Via San Leo 2A, 40054 Vedrana di Budrio, Bologna, Italy.

Correspondence to: Aliai Lanci, Department of Veterinary Medical Sciences, University of Bologna, via Tolara di Sopra 50, 40064 Ozzano Emilia (BO), Italy.

E-mail: aliai.lanci2@unibo.it 


\begin{abstract}
In the mare, foaling is a critical unpredictable event due to a wide range of gestational length and the absence of clear signs of impending parturition. To predict foaling, $\mathrm{pH}$, inversion sodium potassium and increase of calcium concentration in mammary secretions are used. The aim of this study was to find how many days are left until parturition knowing mare's age (A) and parity (P) combined with ultrasonographic measurements of the fetal orbit in Standardbred mares with normal pregnancy. Eighty healthy Standardbred mares with normal pregnancy were hospitalized for attended delivery. Information about mare's age, parity and breeding date were recorded at admission. Transrectal ultrasonography were routinely performed at admission and every 10 days until parturition using a B-mode real time portable unit equipped with a 5-7.5 MHz linear transducer. The images of the fetal orbit were acquired when cornea, anterior and posterior chamber, vitreous body, lens and optic nerve were visible. Longitudinal diameter (LD) was considered as the distance between the two ocular poles, within the vitreous body; transverse diameter (TD), perpendicular to LD and bisecting the lens, was measured as the distance between cornea and retina. At delivery, length of pregnancy and gestational age at each exam were registered. For each ultrasound examination, days before parturition (DBP) were calculated. Seventy-eight Standardbred mares with normal pregnancies were included in the study. Mares' mean age was $9 \pm 5$ years old (range 4-20 years) and mean gestation length was $341 \pm 7$ days (range 327-366 days). Thirty-three mares were primiparous and 45 mares were multiparous. Data were analyzed using a regression tree: P, A, LD and TD were used as covariates. DBP was used as the variable of interest. Nine terminal nodes were identified based on the selected covariates. The first split is produced by the TD: fetuses with TD greater or equal than $2.97 \mathrm{~cm}$ are further split according to LD, with a threshold of $3.28 \mathrm{~cm}$. The next split is dictated by A; after a further split on LD, the first terminal node is built, containing 34 fetuses with average DBP equal to 10 days. If the $\mathrm{A}$ is $\geq 9.5$ years a further split is on P: when mares are multiparous, the TD built two different nodes. Since prediction of mare's foaling date is an important factor in stud farm management, the regression model developed may help the veterinarian to estimate the DBP in Standardbred mares with normal pregnancy.
\end{abstract}

Keywords: fetal eye, Standardbred mares, transrectal ultrasonography, predicting parturition, regression tree. 


\section{INTRODUCTION}

In the mare, foaling is an unpredictable and critical event due to a wide range of gestational length and the absence of clear and constant signs of impending parturition [1]. Moreover, most mares foaled late at night or early in the morning. Signs of impending parturition include the development of the udder, waxing of the teat ends, relaxation of the vulvar lips, change in consistency and appearance of milk and sinking of the tail head on either side as the ligaments of the pelvis relax [2,3]. These signs could be indicative of foaling, but there is considerable variation among mares, since none of them is an accurate predictor of impending parturition.

The only method to predict the day of foaling is to identify the increase of calcium concentration in mammary secretions, which occurs 24-12 hours before foaling [4-7]. More recently, some studies showed a decline of $\mathrm{pH}$ in mammary secretion of normal pregnant mares [8-10].

Estimate the date of foaling could be further complicated by an unknown breeding date.

In equine reproduction, transrectal ultrasonography is the most important technique to evaluate the pregnancy; it is a quick and easy on-farm procedure that is widespread among reproduction specialists. With transrectal ultrasonography the fetal orbit is easily accessible in the last month of pregnancy, and its measurement has been widely used to estimate both fetal growth [11-14] and gestational age [15-16]. Turner et al. [15] and Hartwig et al. [16] developed a formula for predicting parturition or gestational age in ponies and Crioulo mares, using ocular longitudinal diameter.

In the mare, due to the fetus' size at term, only aortic diameter and ocular measurements are easily observable during the entire pregnancy [12,17-19]. At term, transrectal ultrasonographic measurement of the fetal eye is an easy on-farm procedure, also used for the evaluation of the combined thickness of uteroplacental unit at the ventral aspect of the cervical pole [11]. The fetal aortic diameter can be visualized only with transabdominal ultrasonography, which requires more time, clipping of the abdomen and a $2.5 \mathrm{MHz}$ transducer with a depth setting of $30 \mathrm{~cm}[20]$.

We hypothesized that ultrasonographic measurement of the fetal orbit in Standardbred could help the practitioners in predicting days before parturition. The purpose of this study was to find how many days are left until parturition using data information known by the breeder, such as mare's age and parity, combined with ultrasonographic measurements of the fetal orbit in Standardbred mares with normal pregnancy. 


\section{MATERIAL AND METHODS}

\subsection{Animals}

Eighty healthy Standardbred mares with normal pregnancy and healthy foals were enrolled in the study. All the mares were housed for attended delivery at the Equine Perinatology and Reproduction Unit - Department of Veterinary Medical Sciences - University of Bologna, during four breeding seasons (2014-2017).

The mares were hospitalized at about 310 days of pregnancy, and remained under observation for at least 7 days postpartum. They were housed in separate $4 * 4 \mathrm{~m}$ straw-bedded boxes, fed hay ad libitum and concentrates twice a day and were allowed to go to pasture during the day. Information about mare's age, parity and breeding date were recorded at admission.

Transrectal ultrasonography were routinely performed at admission and every 10 days until parturition using a B-mode real time portable unit (Aloka Prosound 2; Hitachi Aloka Medical Ltd., Tokyo, Japan) equipped with a 5-7.5 MHz linear transducer. The mares were restrained in steel stock, with both sides opened and sedation was always avoided. The duration of transrectal ultrasound examinations varied from 5 to 15 minutes.

\subsection{Data collection}

The images of the fetal orbit were acquired when cornea, anterior and posterior chamber, vitreous body, lens and optic nerve were visible (Fig. 1a). Images were analyzed using the software ImageJ (http:// imagej.nih.gov/ij/). Longitudinal diameter (LD) and transverse diameter (TD) were measured. LD was considered as the distance between the two ocular poles, within the vitreous body; TD, perpendicular to LD and bisecting the lens, was measured as the distance between cornea and retina (Fig. 1b). All measurements were repeated 3 times and the average was calculated.

At delivery, length of pregnancy and days of pregnancy at each exam were registered. For each ultrasound examination, days before parturition (DBP) were calculated with this formula:

$\mathrm{DBP}=$ gestation length - days of pregnancy at each ultrasound examination. 
The foals were classified as healthy when they had an APGAR score $\geq 8$ [21], a normal clinical evaluation during the course of hospitalization, including a complete blood count and serum biochemistry at birth and an $\mathrm{IgG}$ serum concentration $\geq 800 \mathrm{mg} / \mathrm{dL}$ at $18-24$ hours of life.

\subsection{Statistical analysis}

Descriptive statistics of mare's age, parity, DBP, LD and TD, including mean $\pm \mathrm{SD}$ and range (min/max values) were calculated.

Data were analyzed using a regression tree. Regression tree is a recursive algorithm where the full sample is split into smaller groups called 'nodes' [22]. In every step of the procedure, nodes are split according to covariates values, following the criteria of homogeneity: units put together in the same node have similar values for the variable of interest. At the end of the procedure, all units are allocated into terminal nodes. Covariates determine the path to the terminal node. Each node can be characterized by computing averages and variabilities for the variable of interest.

Parity, mare's age, longitudinal diameter and transverse diameter, were used as covariates for the regression tree. Days before the parturition (DBP) was used as the variable of interest.

\section{RESULTS}

Seventy-eight Standardbred mares with normal pregnancies were included in the study, since the ultrasound studies of two mares were not suitable for the ocular image inclusion criteria. Mares' mean age was $9 \pm 5$ years old (range 4-20 years). Thirty-three mares were primiparous and 45 mares were multiparous, the mean parity was $5 \pm 3$ pregnancies (range 1-12). Mean gestation length was $341 \pm 7$ days (range 327-366 days).

One hundred seventy-eight ultrasound examinations were performed, but 132 ultrasound evaluations were included; forty-six images were excluded because the ocular images were not appropriate for inclusion criteria. Two examinations were excluded from the statistical analysis because there were two values of DBP which may be considered outliers. The included ultrasonographic evaluation were performed between 293 and 357 days of gestation. 
Results of the regression tree algorithm are visualized in Fig. 2. The following covariates were used to determine the terminal nodes: transverse diameter (TD), longitudinal diameter (LD), mare's age (A) and parity (P). Nine terminal nodes were identified based on the selected covariates; for each terminal node, boxplots of DBP are shown. Averages and standard deviations of each terminal node are reported in Table 1. Covariates splitting the nodes in the top part of the tree can be regarded as more important in discriminating between DBP. Different paths lead to different nodes. The first split is produced by the TD, with a threshold of $2.97 \mathrm{~cm}$ : fetuses with TD greater or equal than 2.97 are further split according to LD, with a threshold of $3.28 \mathrm{~cm}$. Following the path, next split is dictated by mare's age (A): for mares younger than 9.5 years, after a further split on LD the first terminal node (node 5) is built, containing 34 fetuses with average equal to 10 days. If the mare's age is $\geq 9.5$ years a further split is on parity: when mares are multiparous the TD built two different nodes (node 9 and 10). For instance, in Node 14 there are 9 foals with average DPB equal to 18 days, all having transverse diameter greater or than $2.97 \mathrm{~cm}$, longitudinal diameter smaller than $3.28 \mathrm{~cm}$, and further classified by having transverse diameter smaller than $3.09 \mathrm{~cm}$.

\section{DISCUSSION}

In veterinary medicine, fetal morphometry is used to evaluate fetal development, to estimate gestational age and could be useful for predicting parturition. Normal gestation length in Standardbred mares ranges between 322 and 389 days [23-25] and it could be influenced by many factors such as season, sex [26], daylight [27,28], geographical region, latitude [25,29,30], sire [23], mare's age and parity [31-37]. The selected covariates used for the regression tree (the two ocular diameters, mare's age and parity) were the ones that from a practical point of view are available for the veterinary practitioner. Foal's sex and daylight were not used as covariates because breeders and practitioners usually do not know them. The stallion effect was found to contribute only $1 \%-3 \%$ to the variation of gestational length [35-37] and for this reason, it was not considered as a covariate.

About mare's age and parity, they are controversial. Davies Morel et al. [26] did not found any relationship between mare's age and gestational length, but other studies conducted in different breeds found it. Satué et al. [34] found that gestational length was influenced by mare's age and parity: older mares and primiparous mares had a longer gestational length. The authors hypothesized that with increasing age there is a progressive degenerative change in the endometrium that might potentially reduce its nutritive capacity for 
the development of the fetus [31,37-38]. Recent studies confirmed that primiparous mares produce smaller foals compared to multiparous $[39,40]$.

The equine fetal ocular measurements were investigated in several studies: longitudinal diameter $[15,16]$, both longitudinal and transverse diameter [12], circumference and area of vitreous body [13]. In the previous studies [12,14-16,19], the two calipers were positioned excluding the anterior chamber to measure the transverse diameter. In this study, the transverse diameter was measured including the anterior chamber from the cornea to the retina as described by other studies about the ultrasonographic ocular measures of the growing foal $[41,42]$ and adult horse [43]. The TD, which is axial globe length (AGL), was measured as the distance from the central cornea to the retina and the LD, the longitudinal globe length (LGL), was measured as the distance from the lateral globe to the medial globe through the long axis of the lens [41,42].

The regression tree obtained showed that both the diameters might help in predicting parturition. What is interesting to note is the influence of mare's age and parity in the regression results, suggesting that they have some influences in the growth of the fetal eyes and in predicting parturition.

In this study, a group of mares of the same breed and with known breeding dates were included. Ultrasound examinations were performed between 293 and 357 days of pregnancy depending on the hospitalization dates. Differently, Turner et al. [15] included pony mares of different breeds and body weight and with unknown breeding or ovulation dates. Hartwig et al. [16] included Crioulo mares to develop a linear regression model to determine the gestational age based on longitudinal ocular diameter measured parallel to the lens. The fetus orbit diameter of Crioulo mares was also compared with the data obtained in light horses [44] and resulted significantly larger than in light horses. As also suggested by Hartwig et al. [16], this kind of study must be conducted in every single breed because ocular sizes could be different and are not related with the sizes of the horse. The ocular shape is an intrinsic characteristic of the breed as also reported by biometric ultrasonographic measurements of the equine eye $[43,45]$.

The previous formula to calculate DBP [15] and estimate the gestational age [16] refer to a (mixed-effect) linear regression model. By using the regression tree model, which is a non-parametric procedure, some strict assumptions of the other formula, such as normality of the response variable and independent observations, were avoided.

The regression model obtained in this study does not predict exactly the date of parturition, but it could help to estimate how many days are missing in foaling, mostly when the breeding date is not known. From a 
practical point of view, practitioners can follow the structure of the regression tree to determine, based on the splits and the covariate values, which node the new observations refer to. Once the node is determined according to the tree, one has a visualized distribution of the previous observations inside that node, and the average value of the node can be used as a proxy for the predicted DBP. Also, each node as an associated measure of uncertainty, represented by the standard deviation, gives an idea of the variability associated to the predicted DBP.

Further studies are needed to evaluate if the model could be useful during high-risk pregnancy, particularly with intrauterine growth retardation and/or placental problems that influence both the fetal growth and the gestational length.

\subsection{Conclusions}

Since prediction of mare's foaling date is an important factor in stud farm management, the regression model developed, combined with other strategies (e.g. changes in mammary secretions), may help the veterinarian to estimate the days before parturition in Standardbred mares with normal pregnancy.

\section{ACKNOWLEDGMENTS}

The authors thank all the vets and the students of the Unit who helped to perform ultrasound examinations. The authors would like to thank 'Statistics Clinic', a free service provided by statisticians from the Department of Statistics "Paolo Fortunati" (University of Bologna, Italy), for their assistance on the data analysis.

\section{REFERENCES}

[1]. Rossdale PD, Short RV. The time of foaling of thoroughbred mares. J Reprod Fertil 1967;13:341-3. https://doi.org/10.1530/jrf.0.0130341.

[2]. Ley WB. Prefoaling management of the mare and induction of parturition. In: Robinson NE, editor. Current therapy in equine medicine. Philadelphia: WB Saunders Co; 1992, p. 664-8. 
[3]. Christensen BW. Parturition. In: McKinnon AO, Squires EL, Vaala WE, editors. Equine reproduction. Iowa: Wiley-Blackwell; 2011, p. 2267-76.

[4]. Peaker M, Rossdale PD, Forsyth IA, Falk M. Changes in mammary development and composition of secretion during late pregnancy in the mare. J Reprod Fertil Suppl 1979;27: 555-61.

[5]. Leadon DP, Jeffcott LB, Rossdale PD. Mammary secretions in normal spontaneous and induced premature parturition in the mare. Equine Vet J 1984;16:256-9. https://doi.org/10.1111/j. 2042-3306.1984.tb01922.x.

[6]. Ley WB, Bowen JM, Purswell BJ, Irby M, Greive-Crandell K. The sensitivity, specificity and predictive value of measuring calcium carbonate in mares' prepartum mammary secretions. Theriogenology 1993;40:189-98. https://doi.org/10.1016/0093-691X(93)90352-6.

[7]. Turner JL, Todd LP, Arns MJ, Higgins JJ, Minton JE. Case study: use of optical density of mammary secretions to predict parturition in mares. Prof Anim Sci 2002;18:312-5. https://doi.org/10.15232/ S1080-7446(15)31539-4.

[8]. Canisso IF, Ball BA, Troedsson MH, Silva ES, Davolli GM. Decreasing pH of mammary gland secretions is associated with parturition and is correlated with electrolyte concentrations in prefoaling mares. Vet Rec 2013;173:218. http://dx.doi.org/10.1136/vr.101658.

[9]. Korosue K. Testing mammary gland secretions to help predict when a mare will foal. Vet Rec 2013;173:216-7. http://dx.doi.org/10.1136/vr.f5384.

[10]. Hayna JT, Randell SR, Burden CA, Pozor MA, Benson SA, Kelleman AA, Giguère S, Macpherson ML. Mammary gland secretion $\mathrm{pH}$ and impending parturition in ponies and mare with and without firocoxib. J Equine Vet Sci 2018;66. https://doi.org/10.1016/j.jevs.2018.05.135.

[11]. Renaudin CD, Gillis CL, Tarantal AF, Coleman DA. Evaluation of equine fetal growth from day 100 of gestation to parturition by ultrasonography. J Reprod Fertil Suppl 2000;56:651-60.

[12]. Bucca S, Fogarty U, Collins A, Small V. Assessment of feto-placental well-being in the mare from midgestation to term: transrectal and transabdominal ultrasonographic features. Theriogenology 2005;64:542-57. https://doi.org/10.1016/j.theriogenology.2005.05.011. 
[13]. Hendriks WK, Colenbrander B, van der Weijden GC, Stout TA. Maternal age and parity influence ultrasonographic measurements of fetal growth in Dutch Warmblood mares. Anim Reprod Sci 2009;115:110-23. http://doi: 10.1016/j.anireprosci.2008.

[14]. Murase H, Endo Y, Tsuchiya T, Kotoyori Y, Shikichi M, Ito K, Sato F, Nambo Y. Ultrasonographic evaluation of equine fetal growth throughout gestation in normal mares using a convex transducer. J Vet Med Sci 2014;76:947-53. https://doi.org/10.1292/jvms.13-0259.

[15]. Turner RM, McDonnell SM, Feit EM, Grogan EH, Foglia R. Real-time ultrasound measure of the fetal eye (vitreous body) for prediction of parturition date in small ponies. Theriogenology 2006;66:331-7. https:// doi.org/10.1016/j.theriogenology.2005.11.019.

[16]. Hartwig FP, Antunez L, Dos Santos RS, Lisboa FP, Pfeifer LFM, Nogueira CEW, de Rosa Curcio B. Determining the gestational age of Crioulo mares based on a fetal ocular measure. J Equine Vet Sci 2013;33:557-60. https://doi.org/10.1016/j.jevs.2012.08.203.

[17].Whitwell KE, Jeffcott LB. Morphological studies on the fetal membranes of the normal singleton foal at term. Res Vet Sci 1975;19:44-55.

[18]. Reef VB, Vaala WE, Worth LT, Sertich PA, Spencer PA. Ultrasonographic assessment of fetal wellbeing during late gestation: development of an equine biophysical profile. Equine Vet J 1996a;28:200-8. https://doi.org/10.1111/j.2042-3306.1996.tb03773.x.

[19]. Reef VB, Vaala WE, Worth LT, Spencer PL, Sertich PL, Hammett B. Transcutaneous ultrasonographic assessment of fetal well-being during late gestation: a preliminary report on the development of an equine biophysical profile. In: Proceedings of the 42nd Annual Convention of the American Association of Equine Practitioner 1996b;152-3.

[20]. Reef VB. Chapter 9: Fetal ultrasonography In: Reef VB. Equine diagnostic ultrasound. Philadelphia: WB Saunders Co; 1998, p. 425-45.

[21]. Vaala WE. Perinatology. In: Higgins AJ, Snyder JR. The Equine Manual. 2nd ed., W.B. Saunders; 2006, p. $803-4$.

[22]. Breiman L, Friedman J, Stone CJ, Olshen RA. Classification and regression trees. CRC press 1984. 
[23]. Marteniuk JV, Carleton CL, Lloyd JW, Shea ME. Association of sex of fetus, sire, month of conception, or year of foaling with duration of gestation in Standardbred mares. J Am Vet Med Assoc 1998;212:1743-5.

[24]. Villani M, Romano G. Induction of parturition with daily low-dose oxytocin injections in pregnant mares at term: clinical applications and limitations. Reprod Domest Anim 2008;43:481-3. https://doi.org/ 10.1111/j.1439-0531.2007.00940.x.

[25]. Mariella J, Iacono E, Lanci A, Merlo B, Palermo C, Morris L, Castagnetti C. Macroscopic characteristics of the umbilical cord in Standardbred, Thoroughbred and Warmblood horses. Theriogenology 2018;113:166-70. https://doi.org/10.1016/j.theriogenology.2018.03.004.

[26]. Davies Morel MC, Newcombe JR, Holland SJ. Factors affecting gestation length in the Thoroughbred mare. Anim Reprod Sci 2002;74:175-85. https://doi.org/10.1016/S0378-4320(02)00171-9.

[27]. Hodge SL, Kreider JL, Potter GD, Harms PG, Fleeger JL. Influence of photoperiod on the pregnant and postpartum mare. Am J Vet Res 1982;43,1752-5.

[28]. Sharp DC. Transition into the breeding season: clues to the mechanism of seasonality. Equine Vet $\mathbf{J}$ 1988;20,159-61. https://doi.org/10.1111/j.2042-3306.1988.tb01488.x.

[29]. Dicken M, Gee EK, Rogers CW, Mayhew IG. Gestation length and occurrence of daytime foaling of Standardbred mares on two stud farms in New Zealand. N Z Vet J 2012;60:42-6. https://doi.org/ 10.1080/00480169.2011.632340.

[30]. Vincent SM, Evans MJ, Alexander SL, Irvine CHG. Establishing normal foaling characteristics in Standardbred mares in New Zealand. J Equine Vet Sci 2014;34:217-9. https://doi.org/10.1016/j.jevs. 2013.10.157.

[31]. Ricketts SW, Alonso S. The effect of age and parity on the development of equine chronic endometrial disease. Equine Vet J 1991;23:189-92. https://doi.org/10.1111/j.2042-3306.1991.tb02752.x.

[32]. Wilsher S, Allen WR, 2003. The effects of maternal age and parity on placental and fetal development in the mare. Equine Vet J 35: 476-483. https://doi.org/10.2746/042516403775600550

[33]. Valera M, Blesa F, Dos Santos R, Molina A. Genetic study of gestation length in andalusian and arabian mares. Anim Reprod Sci 2006;95:75-96. https://doi.org/10.1016/j.anireprosci.2005.09.008. 
[34]. Satué K, Felipe M, Mota J, Muñoz A. Gestation length in Carthusian broodmares: effects of breeding season, foal gender, age of mare, year of parturition, parity and sire. Polish J Vet Sci 2011;14:173-80. https:// doi.org/10.2478/v10181-011-0027-6.

[35]. Langlois B, Blouin C. Genetic parameters for gestation length in French horse breeds. Livest Sci 2012;146;133-9. https://doi.org/10.1016/j.livsci.2012.02.028.

[36]. Christmann A, Sieme H, Martinsson G, Distl O. Genetic and environmental factors influencing gestation length and parturition conception interval in Hanoverian warmblood. Livest Sci 2017;199:63-8. https://doi.org/10.1016/j.livsci.2017.03.011.

[37]. Ewert M, Lüders I, Böröcz J, Uphaus H, Distl O, Sieme H. Determinants of gestation length in Thoroughbred mares on German stud farms. Anim Reprod Sci 2018;191:22-33. https://doi.org/10.1016/ j.anireprosci.2018.02.001.

[38]. Morris LHA, Allen WR. Reproductive efficiency of intensively managed Thoroughbred mares in Newmarket. Equine Vet J 2002;34:51-60. https://doi.org/10.2746/042516402776181222.

[39]. Robles M, Peugnet PM, Valentino SA, Dubois C, Dahirel M, Aubrière MC, Reigner F, Serteyn D, Wimel L, Tarrade A, Chavatte-Palmer P. Placental structure and function in different breeds in horses. Theriogenology 2018a;108:136-45. https://doi.org/10.1016/j.theriogenology.2017.11.007.

[40]. Robles M, Dubois C, Gautier C, Dahirel M, Guenon I, Bouraima-Lelong H, Viguié C, Wimel L, Couturier-Tarrade A, Chavatte-Palmer P. Maternal parity affects placental development, growth and metabolism of foals until 1 year and a half. Theriogenology 2018b;108:321-30. https://doi.org/10.1016/ j.theriogenology.2017.12.019.

[41]. Valentini S, Castagnetti C, Musella V, Spinella G. Assessment of intraocular measurements in neonatal foals and association with gender, laterality, and body weight: a clinical study. PLoS One. 2014; 9:e109491. https://doi.org/10.1371/journal.pone.0109491.

[42]. Herbig LE, Eule JC. Central corneal thickness measurements and ultrasonographic study of the growing equine eye. Vet Ophthalmol 2015;18:462-71. https://doi.org/10.1111/vop.12252.

[43]. Barsotti G., Citi S., Brovelli M., Mussi E., Luchetti E., Carlucci F., Sgorbini M. Equine ocular ultrasonography: Evaluation of some biometric measurements. Ippologia 2010;21:39-43. 
[44]. Kähn VW, Leidl W. Die ultraschall-biometrie von pferdefeten in utero und die sonographische darstellung ihrer organe. Dtsch Tierarztl Wschr 1987;94:509-15.

[45]. McMullen RJ, Gilger BC. Keratometry, biometry and prediction of intraocular lens power in the equine eye. Vet Ophthalmol 2006;9:357-6. https://doi.org/10.1111/j.1463-5224.2006.00493.x. 